\title{
IMPLEMENTASI SMS GATEWAY PADA SISTEM INFORMASI KESISWAAN SEKOLAH MENENGAH ATAS NEGERI (SMAN) 1 PRAYA TENGAH MENGGUNAKAN METODE EXTREME PROGRAMMING (XP)
}

\author{
Wire Bagye ${ }^{1}$, Muhammad Salehudin², Khairul Imtihan, ${ }^{3}$ \\ 1,2Program Studi Teknik Informatika, STMIK Lombok \\ ${ }^{3}$ Sistem Informasi, STMIK Lombok
}

Jln. Basuki Rahmat No. 105 Praya Lombok Tengah Phone: (0370) 653109 Kode Pos: 83511

Praya,NTB, Indonesia

wirestmik@gmail.com ${ }^{1}$, saleh999stmik@gmail.com ${ }^{2}$, khairulimtihan31@gmail.com $^{3}$

\begin{abstract}
The process of delivering information to students in 1 praya high school is using a letter. Problems that occur are students who often do not attend the expected activities in the afternoon. Guardians of students also cannot use or learn about performance and activities while at school. To support the information delivery activities at the 1 praya Middle School to the guardian, students develop a student information system using the Extreme programming (XP) method. By utilizing the SMS Gateway technology. This system runs information for students who do not take lessons. The results of the system testing obtained from the information system application at SMAN 1 praya middle can run well as expected. When an admin sends information to students, it can be done faster than sending a letter.
\end{abstract}

Keywords : Student Information System, Extreme Programming (XP), SMS Gateway.

\section{Abstrak}

Proses penyampaian informasi kepada wali murid pada SMA Negeri 1 praya tengah menggunakan surat. Permasalahan yang terjadi ialah siswa sering tidak mengikuti kegiatan jika dijadwalkan pada sore hari. Wali murid juga tidak dapat memantau atau mengetahui kinerja dan aktifitas anaknya selama berada di sekolah. Untuk menunjang kegiatan penyampaian informasi pada SMAN 1 praya tengah ke wali murid dikembangkan sebuah aplikasi sistem informasi kesiswaan menggunakan metode Extreme programming (XP). Dengan memanfaatkan teknologi SMS Gateway. System ini berfungsi menyebarkan informasi kepada wali murid jika siswa tidak mengikuti pelajaran. Hasil dari pengujian sistem didapatkan bahwa aplikasi sistem informasi kesiswaan di SMAN 1 praya tengah dapat berjalan dengan baik sesuai yang diharapkan. Sehingga saat admin melakukan pengiriman informasi kepada wali murid dapat dilakukan lebih cepat dibandingkan dengan cara mengirim surat.

Kata Kunci : Sistem Informasi Kesiswaan, Extreme Programming (XP), SMS Gateway.

\section{PENDAHULUAN}

Kesiswaan merupakan bagian yang penting dalam sebuah sekolah terutama di SMA Negeri 1 Praya Tengah. Selama ini sekolah-sekolah dalam hal penyelenggaraan pendidikan seperti jadwal kegiatan ekstrakurikuler, jadwal ujian tengah semester, ujian akhir semester, daftar nilai siswa, masih dilakukan dengan konvensional dibantu dengan pemanfaatan program Microsoft Excel dan micrososft word. Microsoft Excel dan Microsoft word telah cukup membantu dalam pemrosesan data. Data-data tersebut tidak terintegrasi maka kesalahan, redudansi dan ketidak akuratan data sangat mungkin untuk terjadi. Hal ini akan menyebabkan kinerja guru yang mengelola data akan terganggu dan membutuhkan waktu lama.

SMA Negeri 1 praya tengah pada saat ini proses penyampaian informasi kepada wali murid masih menggunakan surat. Kegiatan siswa diluar jam sekolah yang sering disalah gunakan oleh para siswa. Siswa minta izin kepada orang tua dengan alasan mengikuti 
kegitan ekstrakulikuler, tetapi tidak datang ke sekolah tanpa sepengetahuan orang tua/wali murid. Selain itu jika SMA Negeri 1 praya tengah masih menggunakan system konvensional, selain proses pengerjaan yang cukup lama, wali murid juga tidak dapat memantau atau mengetahui kinerja dan aktifitas anaknya selama berada di sekolah. Selain itu, jika proses penyampaian jadwal ujian tengah semester maupun akhir semester masih ditempel di madding, tidak jarang disobek oleh siswa-siswa yang berperilaku nakal, sehingga kejadian ini dapat merugikan siswa-siswa lain yang belum mengetahui informasi tersebut.

Berdasarkan permasalahan yang ada di SMA Negeri 1 Praya Tengah maka solusi yang dapat ditawarkan ialah sistem informasi kesiswaan dengan menggunakan metode pengembangan extreme programming $(X P)$, Pengembangan sistem yang cepat dan berkualitas dengan menggunakan kerangka kerja eXtreme Programming (XP). Pengembangan perangkat lunak harus direncanakan dengan baik, sehingga mendapatkan perangkat lunak yang berkualitas dan sesuai dengan kebutuhan pengguna (user). Pemilihan kerangka kerja (metodologi) yang tepat akan menentukan keberhasilan pengembangan perangkat lunak, sehingga menghindari tambal sulam dalam pengembangan aplikasi[10].

\section{PUSTAKA DAN TEORI}

\section{A. Tinjauan Pustaka}

Untuk membantuk karakter siswa yang berbudi luhur maka pihak sekolah membutuhkan peran wali murid dalam mewujudkannya. Pelanggaran yang dilakukan siswa dirasa sangat penting untuk diketahui oleh wali siswa dalam waktu yang singkat yaitu pada hari yang sama untuk mempercepat pengambilan tindakan. dibutuhkan aplikasi untuk mempercepat proses informasi antara sekolah dan orang tua dalam hal ketertiban siswa sehingga orang tua dapat bekerja sama dengan pihak sekolah untuk membantu menangani kenakalan siswa. Dengan adanya sistem informasi poin pelanggaran dan prestasi siswa berbasis sms gateway pada Sekolah Menengah Kejuruan Negeri 3 Pacitan diharapkan orang tua mengetahui pelanggaranpelanggaran anaknya secara cepat sehingga dapat memperkecil tingkat kenakalan siswa disekolah[8].

Sistem informasi siswa berbasis sms gateway menyediakan informasi tentang siswa sekolah yang dapat diakses melalui ponsel dengan format SMS yang ditentukan. siswa atau orang tua dapat mengakses informasi dari sekolah tanpa harus datang langsung ke sekolah. Aplikasi ini dijalankan berbasis desktop stand alone. Aplikasi gateway SMS akan membantu siswa mendapat informasi tentang siswa dan sekolah setiap hari melalui teks.aplikasi ini juga sekaligus menyelesaikan permasalahan wali murid yang berhaangan hadir untuk mendapatkan informasi tentang kegiatan siswa. System memberikan layanan yaitu Menyajikan informasi hasil tes harian dan Menyajikan entri informasi log kegiatan siswa serta Sebagai media siaran untuk menyebarkan pengumuman tentang kegiatan sekolah kepada siswa dan wali murid. System dikembangkan menggunakan Microsoft Visual Basic 6 dan MySQL sebagai databasenya. Hasil penelitian siswa dapat mengakses informasi dari sekolah tanpa harus datang langsung ke sekolahb dengan mengirim SMS ke layanan informasi dengan format SMS yang telah ditentukan kemudian secara otomatis system akan merespon langsung[4].

SIM berbasis SMS Gateway di SMP Al Islam Krian dikembangkan untuk memberikan informasi kepada pihak luar melalui bantuan teknologi informasi berbasis Gateway untu k meningkatka ketertiban siswa. Implementasi ini melalui tahapan mengumumkan penerapan, mendapatkan sumber daya perangkat lunak, menyiapkan database, menyiapkan fasilitas, mendidik fasilitas,mendidik peserta dan pemakai, dan masuk ke sistem baru. Manfaat dari pengembangan SMS Gateway di sekolah tersebut ialah dapat dilakukan peneyebaran informasi secara serentak ke nomor handphone walimurid dan siswa yang terdaftar dalamsystem[2].

Sebuah aplikasi SMS Gateway untuk menunjang informasi perpustakaan dibangun sebagai upaya meningkatkan aktivitas siswa serta meningkatkan kualitas pendidikan dan pangajaran sehingga memudahkan petugas perpustakaan dalam mengelola sistem informasi perpustakaan dan menyampaikan informasi kepada anggota perpustakaan dengan format 
SMS. Penerapan SMS Gateway untuk menunjang informasi perpustakaan sangatlah efektif yaitu lebih mudah dan cepat dalam menyampaikan informasi. Hasil yang diperoleh dari penelitian ini adalah aplikasi SMS Gateway sebagai sarana penunjang informasi perpustakaan dengan memanfaatkan komputer sebagai alat bantu untuk mengakses data buku diperpustakaan menggunakan layanan SMS [5].

Implementasi teknologi Sort Message Service (SMS) untuk berhubungan antara sesorang dengan system pada Sistem Informasi SMS Gateway untuk Meningkatkan Layanan Komunikasi Sekitar Akademika Fakultas Ilmu Komputer Unsri. Sistem informasi yang dihasilkan memberikan akses control sesuai dengan kebutuhan user seperti dekan dapat memberikan disposisi langsung kepada pembantu dekan, Kepala tata usaha dan kepala bagian juga dapat memberikan disposisi dengan karyawan lainnya. Begitu juga dengan ketua jurusan dapat memberikan disposisi ke sekretaris jurusan atau ke semua dosen. Dalam pengembangan sistem dengan SMS Gateway menggunakan teknologi Gammu untuk pengiriman pesan. Dalam pengembangan sistem ini peneliti menggunakan metode Fast sebagai metode pengembangan perangkat lunak. sistem memberikan kemudahan laju pencapaian tujuan institusi secara global sedangkan secara khusus penggunaan sistem ini membantu penyampaian disposisi yang sekaligus bisa berisi perintah kerja maupun informasi tersampaikan secara real time [1].

\section{B. SMS Gateway}

SMS gateway adalah suatu sistem yang menjembatani antara handphone dengan system yang menjadi server dengan SMS sebagai informasinya. SMS adalah sebuah teknologi yang menyediakan pelayanan pengiriman dan penerimaan pesan antar mobile phone dalam GSM, CDMA dan TDMA. 2. Sebuah SMS hanya dapat menampung maksimal 140 bytes data yaitu satu SMS dapat menampung 160 karakter latin atau 70 karakter non latin. SMS teks mendukung untuk bahasa hampir semua negara, termasuk juga china, korea, arab, jepang.. 3. SMS gateway adalah suatu sistem yang menjembatani antara handphone dengan sistem yang menjadi server dengan SMS sebagai informasinya 4. Untuk menjalankan aplikasi SMS gateway diperlukan komponen-komponen PC,
Hand phone, dan aplikasi penunjang [9].

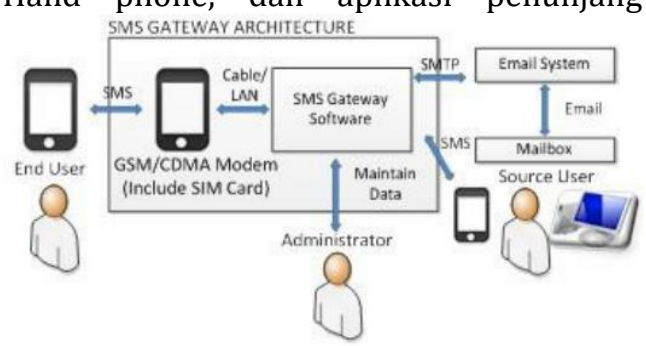

Gambar 2.1. arsitektur SMS Gateway

Aplikasuk pengembangan SMS Gatewai antara lain

1. Gammu dasarnya sebuah library untuk membangkitkan SMS Gateway yang bersifat open source dan mendukung banyak jenis modem. pengembangan menggunakan script PHP dan database MySQL. Wammu merupakan versi GUI dari Gammu.

2. Kalkun merupakan SMS Gateway open source berbasis web yang tidak memerlukan coding. fitur menarik dari aplikasi Kalkun ini yaitu Multiple database backend, Multiuser, Conversation, Flash SMS, Custom folder management, Phonebook management, SMS bomber, SMS advertisement, SMS content/member, Simple Auto Reply, dan Unicode support.

3. PlaySMS merupakan sistem portal mobile berbasis web yang fleksibel dalam menangani layanan-layanan seperti SMS Gateway, bulk SMS, personal messaging systems, hingga alat komunikasi korporasi.

4. Kannel merupakan aplikasi open source untuk WAP dan SMS Gateway yang hanya dapat dikembangkan di dalam sistem linux.. Pengebangan mengunakan script perintah dasar yang disediakan oleh Kannel.

\section{Extreme Programming (XP).}

Pengembangan sistem yang cepat dan berkualitas dengan menggunakan kerangka kerja Extreme Programming (XP). Pengembangan perangkat lunak harus direncanakan dengan baik, sehingga mendapatkan perangkat lunak yang berkualitas dan sesuai dengan kebutuhan pengguna (user)[10]. 


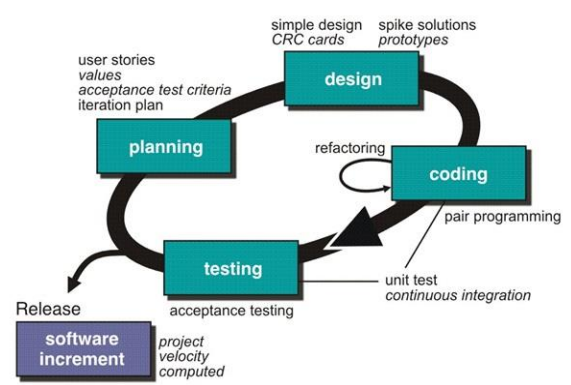

Gambar 2.2. Kerangka kerja extreme programming[10]

Tahap-tahap yang dilakukan dalam setiap iterasi sebagai berikut :

1. Planning and Analysis User stories ditulis dalam format kalimat menggunakan istilah umum (Metaphor) yang dapat dan mudah dimengerti. User stories yang sudah dibuat selanjutnya diurutkan berdasarkan prioritas mana yang akan dikerjakan diimplementasikan terlebih dahulu.

2. Desain Tahap ini merupakan tahap desain aplikasi sederhana. Alat yang digunakan untuk mendesai menggunakan Responsibilities, and Collaboration (CRC) Cards. Sebuah CRC Card digunakan untuk menggambarkan objek dari segi class, tugas yang diberikan, dan class lain yang berkolaborasi. CRC Card perlu dibuat secara jelas agar rancangan aplikasi Web yang dikembangkan dapat dijelaskan kepada setiap orang.

3. Coding merupakan hal utama dalam pengembangan aplikasi menggunakan metode XP adalah pair programming atau melibatkan 2 atau lebih proghrammer.

4. Testing tahap ini memfokuskan pada pengujian fitur-fitur yang ada pada aplikasi sehingga tidak ada kesalahan dan aplikasi yang dibuat sesuai dengan proses bisnis pada klien.

\section{METODOLOGI PENELITIAN}

\section{A. Analisa Masalah}

Pada tahap analisa dilakukan beberapa metode pengumpulan data yaitu wawancara dan observasi. Dari hasil analisa yang dilakukan pada SMA Negeri 1 Praya Tengah disimpulan suatu masalah yang berkaitan dengan penyampaian informasi, dimana proses penyampaian informasi masih dilakukan secara konvensional menggunakan selembaran kertas yang ditempelkan di madding. Hal ini sering kali mengakibatkan informasi tidak dibaca oleh semua siswa disebabkan oleh salah satu factor siswa nakal yang suka mencabut atau merobek informasi. Sebab lain disebabkan rasa malas yang dimiliki oleh siswa untuk mencari tahu informasi terbaru yang di keluarkan oleh pihak sekolah.

Saat ini proses penyampaian informasi yang ada dianggap kurang cepat dan kurang efisien untuk siswa dan informasi yang disampaikan ke orang tua murid. Informasi yang diberikan kepada wali murid tentang kegiatan yang dilakukakan oleh siswa pada saat berada di sekolah menggunakan selebaran kertas yaitu dalam bentuk surat pemberitahuan orang tua wali. Pihak sekolah memberikan surat ke wali murid denganmenitipkan pada siswa agar diserahkan ke orang tua wali. Sebagian siswa yang merasa memiliki masalah disekolah tidak menyerahkan ke wali murid dengan alasan agar orang tua tidak mengetahui bagaimana kelakuan dan prestasi yang dimilikinya selama di sekolah.

Untuk mengetahui tingkat keberhasilan dalam proses pengiriman informasi, perlu dilakukan tahapan identifikasi faktor kunci keberhasilan dengan menggunakan analisa PIECES. Untuk mengidentifikasi masalah, haruslah dilakukan analisa terhadap performance, information, economic, control, efficiency, dan services. Dari hasil analisis dapat diuraikan sistem yang sedang berjalan pada SMAN 1 Praya Tengah yaitu dapat dijelaskan pada gambar flowmap yang sedang berjalan sebagai berikut :

\section{Flowmap kegiatan absensi berjalan}

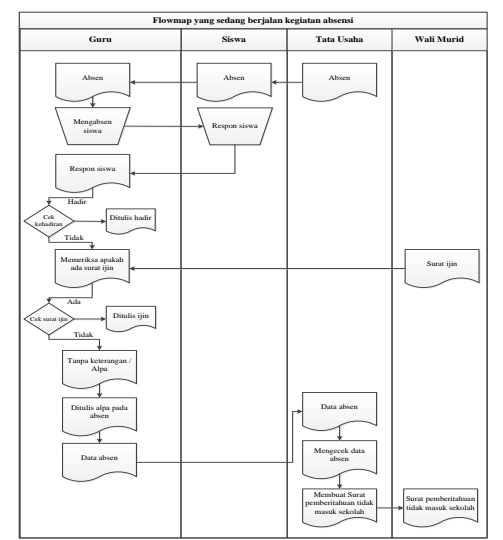

Gambar 3.1 flowmap kegiatan absensi 
Flowmap penilaian yang berjalan

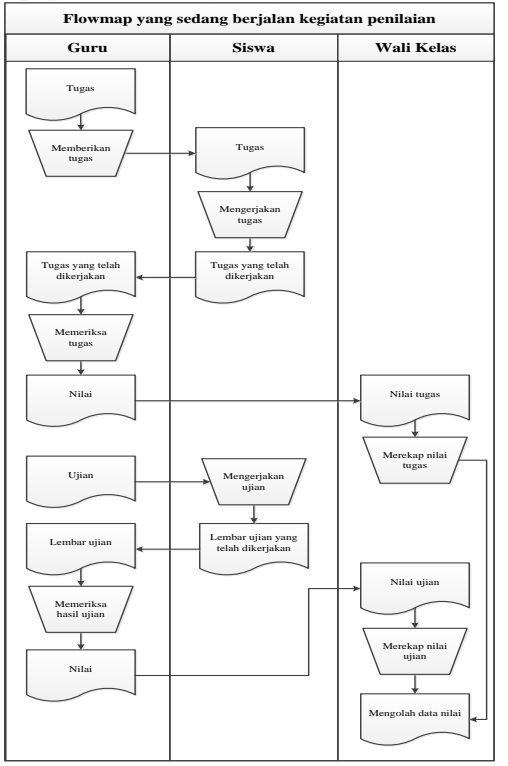

Gambar 3.2 flowmap penilaian berjalan

Flowmap kegiatan ekstrakurikuler berjalan

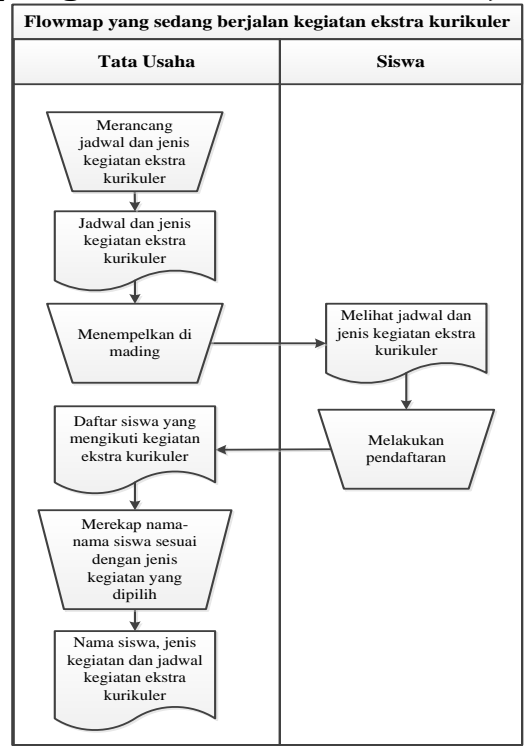

Gambar 3.3 flowmap kegiatan ekstrakurikuler berjalan

Sistem yang diusulkkan pada SMA Negeri 1 Praya Tengah yaitu sistem informasi kesiswaan menggunakan metode Extreme Programming (EP) Menggunakan perangkat tambahan berupa modem dan aplikasi pendukung Gammu untuk penunjang SMS Gateway. Sistem pelayanan akan dibangun dalam bentuk aplikasi web menggunakan bahasa pemrograman PHP database MYSQL yang akan mempermudah admin dalam mengolah informasi siswa.

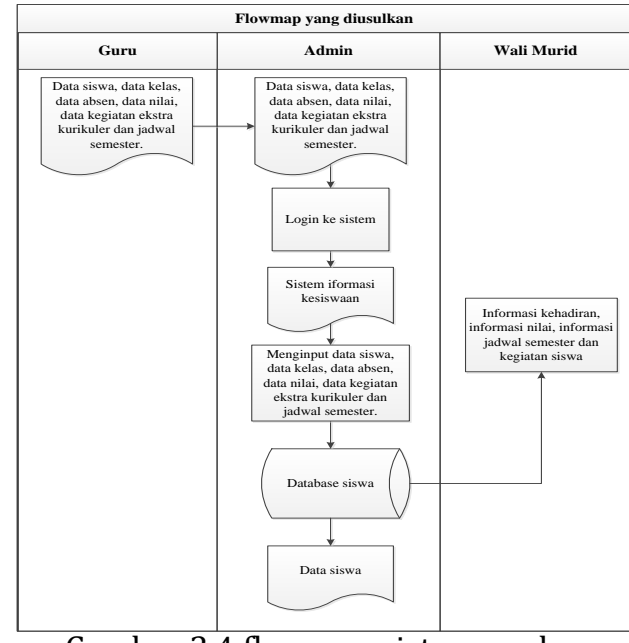

Gambar 3.4 flowmap sistem usulan

\section{B. Perancangan Sistem}

Pada pnelitian ini penulis merancang sistem aplikasi SMS Gateway sebagai sarana penyampaian informasi pada SMAN 1 Praya Tengah menggunakan metode pengembangan Extreme Programming (XP). Adapun tahap-tahap dalam metode pengembangan XP yaitu Planning, Design, Coding, dan Testing.

\section{Data Flow Diagram (DFD)}

1. Diagram Konteks

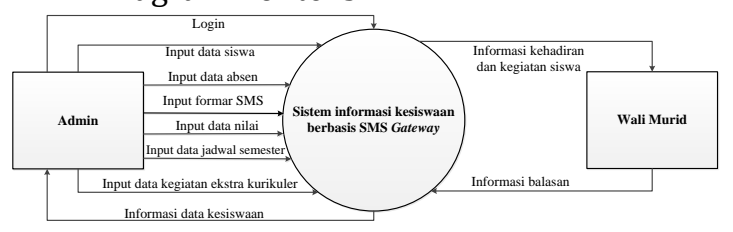

Gambar 3.5 Diagram Konteks

2. DFD Level 1

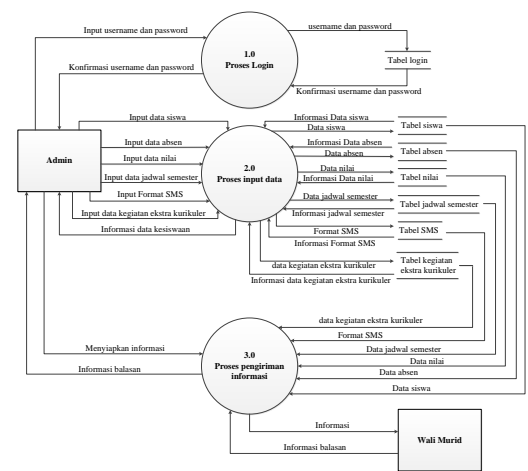

Gambar 3.6 DFD Level 1

3. DFD Level 2 Proses login

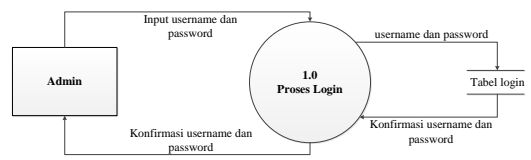

Gambar 3.7 DFD Level 2 proses login 
4. DFD Level 2 Proses input data

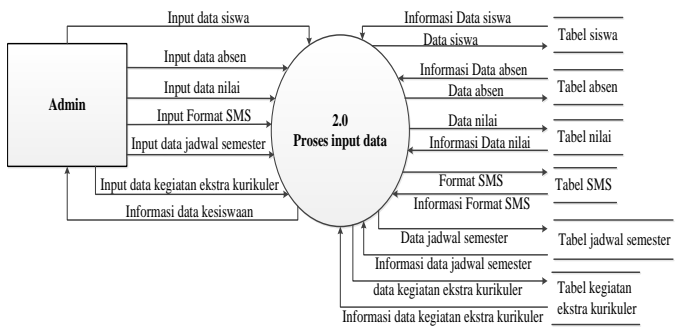

Gambar 3.8 Level 2 proses input data

5. DFD Level 2 proses pengiriman informasi

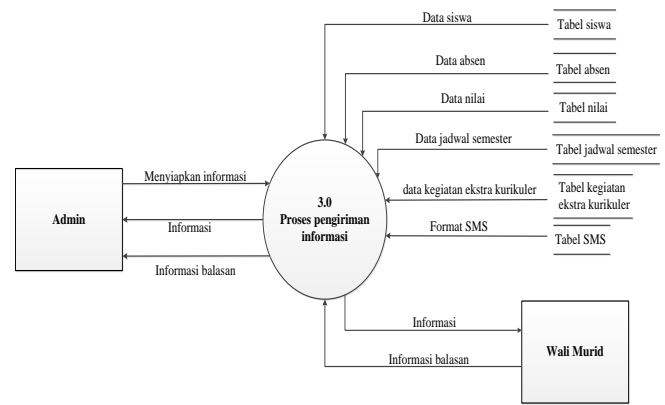

Gambar 3.9 Level 2 proses pengiriman informasi ERD (Entity relationship diagram)

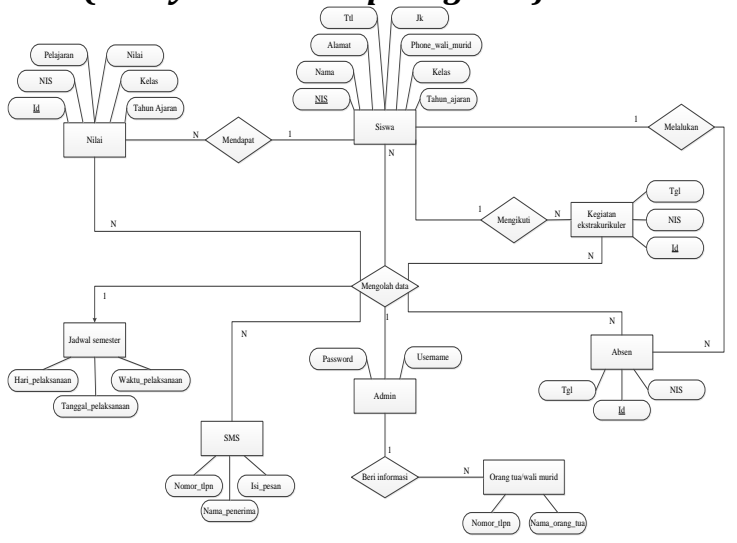

Gambar 3.10 ERD (Entity relationship diagram)

\section{HASIL DAN PEMBAHASAN}

Sebelum program atau aplikasi diterapkan dalam sebuah kantor atau instansi, maka perlu dilakukan pengujian terlebih dahulu untuk mengetahui kesalahan atau eror suatu program. Untuk metode pengujian sistem penulis menggunakan metode pengujian black box, Pengujian ini dilakukan secara black box, yaitu pengujian dilakukan dengan hanya memperhatikan masukan ke sistem dan keluaran dari sistem. Scenario pengujian dijelaskan pada tabel 4.1.
Tabel 4.1 Skenario pengujian sistem

\begin{tabular}{|c|c|c|c|}
\hline 10 & Item Uji & $\begin{array}{l}\text { Detail } \\
\text { Pengujian }\end{array}$ & $\begin{array}{l}\text { Jenis } \\
\text { Pengujian }\end{array}$ \\
\hline 1 & Login & $\begin{array}{ll}\begin{array}{l}\text { Verifikasi data } \\
\text { login user }\end{array} & \\
\end{array}$ & Black box \\
\hline 2 & Pencarian & $\begin{array}{l}\text { Pencarian data } \\
\text { siswa, data user, } \\
\text { absen, data nilai, } \\
\text { data jadwal } \\
\text { semester, dan } \\
\text { data kegiatan } \\
\text { ekstrakurikuler. }\end{array}$ & Black box \\
\hline \multirow{3}{*}{3} & \multirow{3}{*}{$\begin{array}{l}\text { Pengolahan } \\
\text { data siswa }\end{array}$} & Tambah & Black box \\
\hline & & Edit & Black box \\
\hline & & Hapus & Black box \\
\hline \multirow{4}{*}{4} & \multirow{4}{*}{$\begin{array}{l}\text { Pengolahan } \\
\text { data user }\end{array}$} & Tambah & Black box \\
\hline & & Hapus & Black box \\
\hline & & Gembok/kunci & Black box \\
\hline & & $\begin{array}{l}\text { Tambah/ganti } \\
\text { photo }\end{array}$ & Black box \\
\hline \multirow{3}{*}{5} & \multirow{3}{*}{$\begin{array}{l}\text { Pengolahan } \\
\text { data absen }\end{array}$} & Cari & Black box \\
\hline & & Kirim & Black box \\
\hline & & Print data & Black box \\
\hline \multirow{2}{*}{6} & \multirow{2}{*}{$\begin{array}{l}\text { Pengolahan } \\
\text { data nilai }\end{array}$} & Cari & Black box \\
\hline & & Print data & Black box \\
\hline \multirow{2}{*}{7} & \multirow{2}{*}{$\begin{array}{l}\text { Pengolahan } \\
\text { data jadwal } \\
\text { semester }\end{array}$} & Kirim & Black box \\
\hline & & Print & Black box \\
\hline \multirow{3}{*}{8} & \multirow{3}{*}{$\begin{array}{l}\text { Pengolahan } \\
\text { data kegiatan } \\
\text { ekstrakurikule } \\
\mathrm{r}\end{array}$} & Cari & Black box \\
\hline & & Kirim & Black box \\
\hline & & Print data & Black box \\
\hline \multirow{2}{*}{9} & \multirow{2}{*}{$\begin{array}{l}\text { Pengolahan } \\
\text { data inbox }\end{array}$} & Cari & Black box \\
\hline & & Hapus & Black box \\
\hline
\end{tabular}

Berdasarkan skenario pengujian yang telah disusun maka dapat dilakukan pengujian sebagai berikut :

\section{Pengujian proses login}

Tabel 4.2 pengujian proses Login Data Normal Kasus dan Hasil Uji (Data Normal)

\begin{tabular}{|l|l|}
\hline Data masukan & $\begin{array}{l}\text { Username : admin, Password: } \\
\text { admin }\end{array}$ \\
\hline $\begin{array}{l}\text { Yang } \\
\text { diharapkan }\end{array}$ & $\begin{array}{l}\text { Data login dimasukkan, pilih } \\
\text { Username : admin dan isi } \\
\text { Password : admin, lalu klik tombol } \\
\text { login maka dilakukan proses } \\
\text { pengecekan data login. Apabila } \\
\text { data login benar maka admin } \\
\text { mendapatkan haknya sebagai } \\
\text { administrator. }\end{array}$ \\
\hline Pengamatan & $\begin{array}{l}\text { Dapat mengisi data login sesuai } \\
\text { dengan yang diharapkan. }\end{array}$ \\
\hline Kesimpulan & Diterima \\
\hline
\end{tabular}


Tabel 4.3 pengujian proses Login Data salah

\begin{tabular}{|l|l|}
\hline Kasus dan Hasil Uji (Data Salah) \\
\hline Data masukan & $\begin{array}{l}\text { Username : tata usaha, Password : tata } \\
\text { usaha }\end{array}$ \\
\hline $\begin{array}{l}\text { Yang } \\
\text { diharapkan }\end{array}$ & $\begin{array}{l}\text { Data login tidak terdaftar dan } \\
\text { menampilkan pesan kesalahan }\end{array}$ \\
\hline Pengamatan & $\begin{array}{l}\text { Data login tidak terdaftar dan } \\
\text { menampilkan pesan kesalahan }\end{array}$ \\
\hline Kesimpulan & Diterima \\
\hline
\end{tabular}

Kesimpulan dari hasil pengujian Login adalah jika username yang dimasukkan "admin" dan password yang dimasukkan pada form login adalah "admin" maka akan dapat masuk ke halaman utama sistem, sedangkan jika username yang dimasukkan adalah "tata usaha" dan password yang dimasukkan pada form login adalah "tata usaha" maka user tidak dapat masuk ke halaman utama sistem, user akan tetap berada pada halaman login atau form login karena password yang dimasukkan salah. Hasil dari pengujian yang dilakukan penulis menunjukkan bahwa Proses login sudah memenuhi syarat atau sesuai yang diharapkan penulis.

\section{Proses pencarian data siswa}

Tabel 4.4 pengujian proses pencarian data siswa Kasus dan Hasil Uji (data normal)

\begin{tabular}{|l|l|}
\hline Data masukan & ANDRE \\
\hline Yang & Data dengan nama andre diinputkan \\
& pada kolom pencarian, kemudian \\
& sistem akan menampilkan secara \\
& secara otomatis data yang \\
& dibutuhkan oleh admin. Karena \\
& kemungkinan ada lebih dari satu \\
& siswa dengan nama andre, maka \\
& admin dapat menambahkan NIS \\
& siswa untuk membedakannya. \\
\hline Pengamatan & Data andre dapat ditampilkan. \\
\hline Kesimpulan & Diterima \\
\hline
\end{tabular}

Kesimpulan dari hasil pengujian proses pencarian data siswa adalah admin mencari data siswa dengan nama "Andre" dengan cara menginput nama siswa pada form cari data, jika data dengan nama andre tersedia maka sistem akan lansung menampilkan data siswa dengan nama "Andre". Hasil dari pengujian yang dilakukan penulis menunjukkan bahwa Proses pencarian data siswa sudah memenuhi syarat atau sesuai yang diharapkan penulis.

\section{Pengujian data siswa}

Tabel 4.5 pengujian data siswa

\section{Kasus dan Hasil Uji (Data normal)}

\begin{tabular}{|l|l|}
\hline Data masukan & Data siswa \\
\hline Yang & Data siswa di inputkan, dengan cara \\
& $\begin{array}{l}\text { mengisi setiap kolom biodata siswa } \\
\text { dengan lengkap maka aplikasi akan } \\
\text { menampilakn data siswa sesuai dengan }\end{array}$ \\
\hline
\end{tabular}

\begin{tabular}{|l|l|}
\hline & data yang telah di inputkan. \\
\hline Pengamatan & Data siswa dapat ditampilkan. \\
\hline Kesimpulan & Diterima \\
\hline
\end{tabular}

Kesimpulan dari hasil pengujian data siswa adalah admin menginput data siswa dengan cara mengisi kolom biodata siswa dengan lengkap, data yang telah diinputkan akan ditampulkan oleh sistem. Hasil dari pengujian yang dilakukan penulis menunjukkan bahwa Proses pengujian data siswa sudah memenuhi syarat atau sesuai yang diharapkan penulis.

Pengujian data user
Tabel 4.6 pengujian data user
\begin{tabular}{|l|l|}
\hline Kasus dan Hasil Uji (Data normal) \\
\hline Data masukan & Data user \\
\hline $\begin{array}{l}\text { Yang } \\
\text { diharapkan }\end{array}$ & $\begin{array}{l}\text { Data user digunakan untuk login ke } \\
\text { sistem, setiap user memiliki } \\
\text { username dan password yang }\end{array}$ \\
& $\begin{array}{l}\text { berbeda. Data user juga dapat } \\
\text { ditambah sesuai dengan jumlah user } \\
\text { yang berhak mengakses sistem. }\end{array}$ \\
\hline Pengamatan & Data user dapat ditampilkan. \\
\hline Kesimpulan & Diterima \\
\hline
\end{tabular}

Kesimpulan dari hasil pengujian data user adalah menu data user berisikan username dan password yang digunakan untuk login atau mengakses sistem, user dapat login ke sistem jika username dan password benar. Hasil dari pengujian yang dilakukan penulis menunjukkan bahwa Proses pengujian data user sudah memenuhi syarat atau sesuai yang diharapkan penulis.

\section{Pengujian data SMS absen}

Tabel 4.7 pengujian data SMS absen Kasus dan Hasil Uji (Data normal)

\begin{tabular}{|l|l|}
\hline Data masukan & Data siswa tidak hadir \\
\hline $\begin{array}{l}\text { Yang } \\
\text { diharapkan }\end{array}$ & $\begin{array}{l}\text { Data siswa yang tidak hadir dapat } \\
\text { ditampilakan dengan cara menginput } \\
\text { atau mencari berdasarkan NIS siswa. }\end{array}$ \\
\hline Pengamatan & $\begin{array}{l}\text { Data siswa tidak hadir dapat } \\
\text { ditampilkan }\end{array}$ \\
\hline Kesimpulan & Diterima \\
\hline
\end{tabular}

Tabel 4.8 Pengujian Proses pengiriman informasi kehadiran

\begin{tabular}{|l|l|}
\hline \multicolumn{2}{|l|}{ Kasus dan Hasil Uji (Data normal) } \\
\hline Data masukan & NIS : 0009, Nama :ANDRE, Kelas:1A \\
\hline Yang & Setelah data siswa yang tidak hadir \\
& $\begin{array}{l}\text { diinputkan, kemudian admin akan } \\
\text { melakukan pengiriman informasi } \\
\text { kepada wali murid yang bersangkutan. } \\
\text { Informasi yang akan dikirim ke wali } \\
\text { murid berbentuk SMS dengan format } \\
\text { yang telah ditentukan. }\end{array}$ \\
\hline Pengamatan & Informasi sampai ke wali murid \\
\hline kesimpulan & Diterima \\
\hline
\end{tabular}


Kesimpulan dari hasil pengujian data SMS absen adalah data siswa yang tidak hadir dapat ditampilkan dengan cara menginput atau mencari NIS siswa yang bersangkutan. setelah data ditampilka, kemudian admin akan melakukan pengiriman informasi kehadiran kepada wali murid yang bersangkutan, informasi yang diterima wali murid berupa SMS. Hasil dari pengujian yang dilakukan penulis menunjukkan bahwa Proses pengujian data SMS absen dan proses pengiriman informasi kehadiran sudah memenuhi syarat atau sesuai yang diharapkan penulis.

\section{Pengujian data SMS nilai}

Tabel 4.9 Pengujian data SMS nilai Kasus dan Hasil Uji (Data normal)

\begin{tabular}{|l|l|}
\hline Data masukan & Kelas, tahun ajaran, maple \\
\hline $\begin{array}{l}\text { Yang } \\
\text { diharapkan }\end{array}$ & $\begin{array}{l}\text { Kelas, tahun ajaran, maple } \\
\text { diinputkan, kemudian sistem akan } \\
\text { menampilakan data nilai secara } \\
\text { otomatis sesuai dengan data yang } \\
\text { diinputkan oleh admin. Setelah data } \\
\text { tampil, admin dapat menyimpan atau } \\
\text { mengirim data nilai kepada wali } \\
\text { murid. }\end{array}$ \\
\hline Pengamatan & Data nilai dapat ditampilkan \\
\hline kesimpulan & Diterima \\
\hline
\end{tabular}

Tabel 4.10 Pengujian Proses Pengiriman Informasi Nilai

\begin{tabular}{|l|l|}
\hline \multicolumn{2}{|l|}{ Kasus dan Hasil Uji (Data normal) } \\
\hline Data masukan & Data nilai \\
\hline $\begin{array}{l}\text { Yang } \\
\text { diharapkan }\end{array}$ & $\begin{array}{l}\text { Admin akan mengirim informasi } \\
\text { nilai ke setiap wali murid dalam } \\
\text { bentuk SMS dengan format yang } \\
\text { telah ditentukan. }\end{array}$ \\
\hline Pengamatan & Informasi berhasil dikirm \\
\hline kesimpulan & Diterima \\
\hline
\end{tabular}

Kesimpulan dari hasil pengujian data SMS nilai adalah admin menginput data kelas, tahun ajaran, dan mata pelajaran kemudian sistem akan menampilkan data nilai secara otomatis sesuai dengan yang telah diinputkan. Setelah data ditampilkan, kemudian admin dapat mengirim informasi nilai kepada wali murid masing-masing siswa, informasi yang diterima wali murid berupa SMS. Hasil dari pengujian yang dilakukan penulis menunjukkan bahwa Proses pengujian data SMS nilai dan proses pengiriman informasi nilai sudah memenuhi syarat atau sesuai yang diharapkan penulis.
Pengujian data SMS semester

Tabel 4.11 Pengujian data SMS semester Kasus dan Hasil Uji (Data normal)

\begin{tabular}{|l|l|}
\hline Data masukan & Data semester \\
\hline $\begin{array}{l}\text { Yang } \\
\text { diharapkan }\end{array}$ & $\begin{array}{l}\text { admin akan menginputkan atau } \\
\text { memilih data siswa yang akan } \\
\text { dikirimkan jadwal semester dengan } \\
\text { cara menginput data siswa dan } \\
\text { tanggal semester. }\end{array}$ \\
\hline Pengamatan & $\begin{array}{l}\text { Data siswa yang akan dikirim jadwal } \\
\text { berhasil ditampilakn }\end{array}$ \\
\hline kesimpulan & Diterima \\
\hline
\end{tabular}

Tabel 4.12 Pengujian proses pengiriman informasi SMS semester Kasus dan Hasil Uji (Data normal)

\begin{tabular}{|l|l|}
\hline Data masukan & Data semester \\
\hline Yang diharapkan & $\begin{array}{l}\text { Admin akan mengirim jadwal } \\
\text { semester ke setiap siswa dalam } \\
\text { bentuk SMS. }\end{array}$ \\
\hline Pengamatan & $\begin{array}{l}\text { Data jadwal semester berhasil } \\
\text { dikirim }\end{array}$ \\
\hline kesimpulan & Diterima \\
\hline
\end{tabular}

Kesimpulan dari hasil pengujian data SMS semester adalah admin akan menginputkan atau memilih data siswa yang akan dikirimkan jadwal semester dengan cara menginput data siswa dan tanggal semester. Setelah data ditampilkan, kemudian admin dapat mengirim informasi jadwal semester ke setiap siswa, informasi yang diterima siswa berupa SMS. Hasil dari pengujian yang dilakukan penulis menunjukkan bahwa Proses pengujian data SMS semester dan proses pengiriman informasi jadwal semester sudah memenuhi syarat atau sesuai yang diharapkan penulis.

\section{Pengujian data SMS absen ekstrakurikuler}

Tabel 4.13Pengujian data SMS absen (ekstra) Kasus dan Hasil Uji (Data normal)

\begin{tabular}{|l|l|}
\hline Data masukan & $\begin{array}{l}\text { Data siswa tidak hadir kegiatan } \\
\text { ekstrakurikuler }\end{array}$ \\
\hline $\begin{array}{l}\text { Yang } \\
\text { diharapkan }\end{array}$ & $\begin{array}{l}\text { Data siswa yang tidak hadir pada } \\
\text { kegiatan ekstrakurikuler dapat } \\
\text { ditampilkan dengan ara } \\
\text { menginputkan atau mencari } \\
\text { berdasarkan NIS siswa. }\end{array}$ \\
\hline Pengamatan & $\begin{array}{l}\text { Data siswa yang tidak mengikuti } \\
\text { kegiatan ekstrakurikuler berhasil } \\
\text { ditampilakn. }\end{array}$ \\
\hline kesimpulan & Diterima \\
\hline
\end{tabular}


Tabel 4.14 Pengujian proses pengiriman informasi SMS absen (ekstrakurikuler) Kasus dan Hasil Uji (Data normal)

Data masukan $\quad$ Data siswa tidak hadir kegiatan ekstrakurikuler

\begin{tabular}{|l|l|}
\hline $\begin{array}{l}\text { Yang } \\
\text { diharapkan }\end{array}$ & $\begin{array}{l}\text { Admin akan mengirim informasi siswa } \\
\text { yang tidak hadir pada kegiatan } \\
\text { ekstrakurikuler wali murid yang } \\
\text { bersangkutan dalam bentuk SMS } \\
\text { dengan format yang telah ditentukan. }\end{array}$ \\
\hline Pengamatan & $\begin{array}{l}\text { Data siswa yang tidak mengikuti } \\
\text { kegiatan ekstrakurikuler berhasil } \\
\text { dikirim. }\end{array}$ \\
\hline kesimpulan & Diterima \\
\hline
\end{tabular}

Kesimpulan dari hasil pengujian data SMS absen (ekstrakurikuler) adalah Data siswa yang tidak hadir pada kegiatan ekstrakurikuler dapat ditampilkan dengan cara menginputkan atau mencari berdasarkan NIS siswa.. Setelah data siswa ditampilkan, kemudian admin dapat mengirim informasi siswa yang tidak hadir pada kegiatan ekstrakurikuler kepada wali murid yang bersangkutan, informasi yang diterima wali murid berupa SMS. Hasil dari pengujian yang dilakukan penulis menunjukkan bahwa Proses pengujian data SMS absen (ekstrakurikuler) dan proses pengiriman informasi SMS absen (ekstrakurikuler) sudah memenuhi syarat atau sesuai yang diharapkan penulis

\section{Pengujian inbox}

Tabel 4.15 Pengujian inbox Kasus dan Hasil Uji (Data normal)

\begin{tabular}{|l|l|}
\hline Data masukan & Inbox \\
\hline Yang diharapkan & $\begin{array}{l}\text { Inbox ini berisikan SMS balasan dari } \\
\text { wali murid yang sebelumnya } \\
\text { dikirimi informasi. }\end{array}$ \\
\hline Pengamatan & Data inbox berhasil ditampilkan \\
\hline kesimpulan & Diterima \\
\hline
\end{tabular}

Kesimpulan dari hasil pengujian data inbox adalah admin dapat melihat pesan balasan dari wali murid yang sebelumnya dikirimi informasi. Hasil dari pengujian yang dilakukan penulis menunjukkan bahwa Proses pengujian inbox sudah memenuhi syarat atau sesuai yang diharapkan penulis

Berikut adalah tampilan dari sistem informasi kesiswaan di SMAN 1 Praya Tengah.

\section{Halaman login}

Pada halaman login, user diharuskan menginput username dan password agar dapat masuk ke manu utama/beranda sistem.

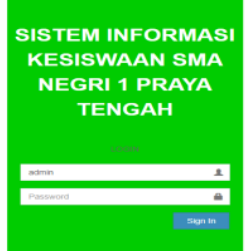

Gambar 4.1 halaman login

\section{Halaman beranda}

Setelah menginput username dan password pada proses login maka akan muncul halaman beranda seperti berikut.

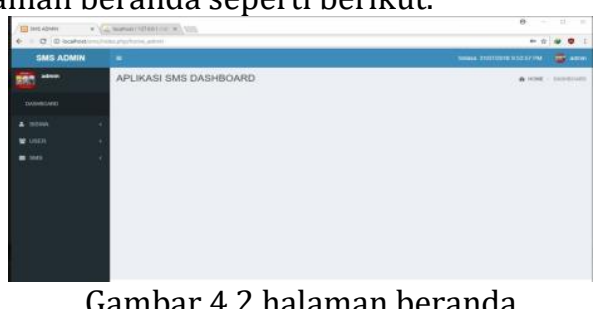

\section{Menu data siswa}

Pada menu data siswa user memiliki fitur cari data dengan disediakannya form cari data. Pada menu data siswa terdapat dua action yakni tombol edit, dan hapus secara berurutan yang memiliki fungsi untuk mengedit data siswa dan menghapus data siswa. Dan terdapat fitur tambah data siswa yang berfungsi untuk menambah data siswa.

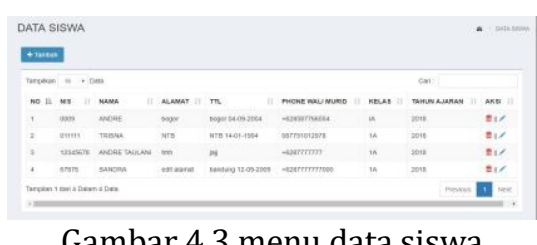

\section{Form tambah data siswa}

Pada form tambah data siswa terdapat delapan form yang terdiri dari form dalam bentuk menu dropdown yang terdiri dari nis, nama, alamat,tempat tanggal lahir, jenis kelamin, kelas, tahun ajaran, dan phone wali murid semua data yang terdapat pada menu dropdown diambil dari data master. Data yang terisi pada form akan tersimpan jika data tersebut tidak diinputkan dua kali dengan data yang sama. 


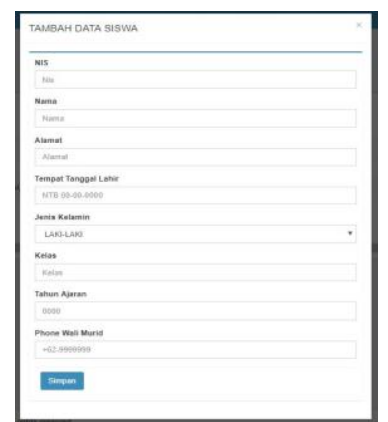

Gambar 4.4 form tambah data siswa

\section{Data user}

Pada menu data user memiliki fitur tambah data admin dengan disediakannya form tambah data. pada menu data user terdapat tiga aksi yakni tombol hapus, edit password user dan ganti foto user secara berurutan yang memiliki fungsi untuk menghapus data user, merubah password dan ganti foto user. Dan terdapat fitur cari data user yang berfungsi untuk mencari data user.

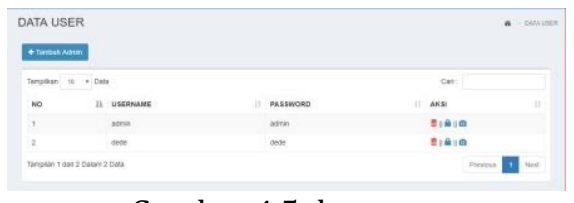

Gambar 4.5 data user

\section{Tambah data user}

Pada menu tambah data user terdapat dua form yang terdiri dari form dalam bentuk menu dropdown yang terdiri dari username dan password, semua data yang terdapat pada menu dropdown diambil dari tabel login atau tabel user.

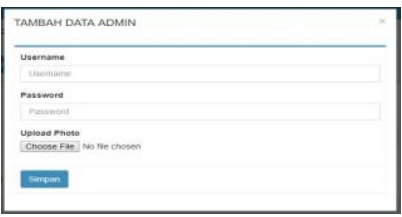

Gambar 4.6 form tambah data user

\section{Menu SMS}

Pada menu SMS terdapat empat sub menu yakni SMS Absen, SMS nilai, SMS absen (eksrakurikuler) SMS dan inbox. Menu-menu ini nantinya akan untuk mengirim informasi kepada wali murid.

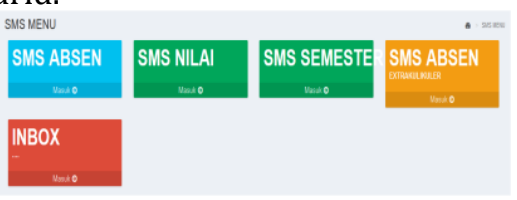

Gambar 4.7 menu SMS

\section{SMS absen}

Pada menu SMS absen ini nantinya akan digunakan untuk mengirim informasi kehadiran kepada wali murid. Pada menu SMS Absen admin akan menginputkan nis siswa yang tidak hadir pada kolom pencarian, setelah nis dan nama siswa tampilan kemudian admin akan mengirim informai kepada wali murid yang bersangkutan. Pada menu SMS Absen terdapat dua button yaitu perintah kirim SMS dan print data SMS.

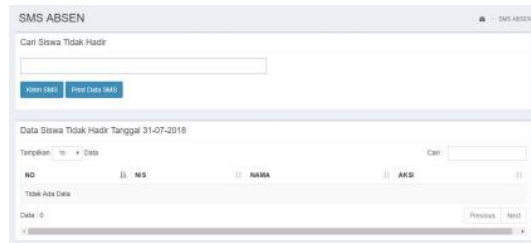

Gambar 4.8 SMS absen

\section{Print data siswa tidak hadir}

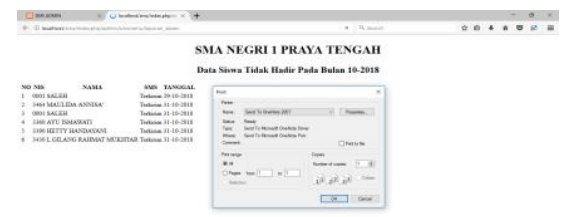

Gambar 4.9 Print data siswa tidak hadir

\section{SMS nilai}

Pada menu SMS Nilai ini digunakan untuk melihat data nilai siswa. Admin hanya perlu menginput atau memilih kelas mana yang akan ditampilkan datanya, setelah nama kelas dipilih maka sistem akan menampilkan data nilai dari kelas tersebut. Pada menu ini terdapat satu button yaitu perintah print data.

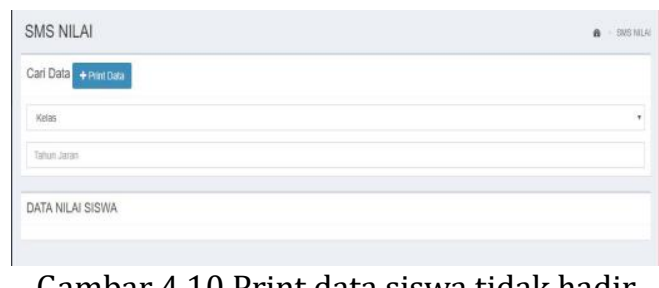

11.Print data nilai

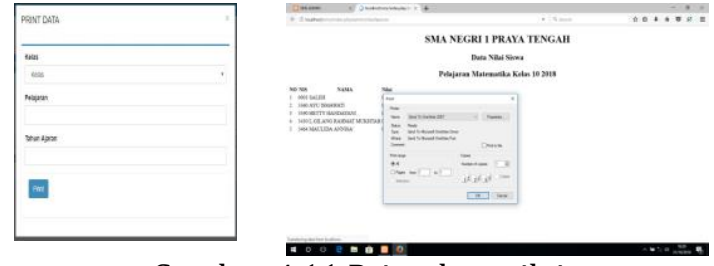

Gambar 4.11 Print data nilai 


\section{SMS jadwal semester}

Pada menu SMS semester digunakan untuk mengirim informasi jadwal semester kesetiap siswa.

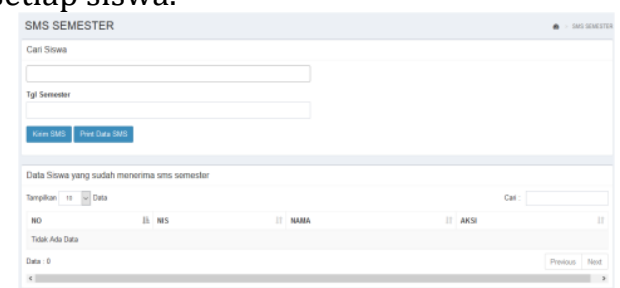

Gambar 4.12 SMS jadwal semester

\section{SMS absen (ekstrakurikuler)}

Pada menu SMS Absen Ekstrakurikuler ini nantinya akan digunakan untuk mengirim informasi kehadiran pada kegiatan ekstrakurikuler kepada wali murid, proses ini sama halnya dengan pengiriman informasi absensi.

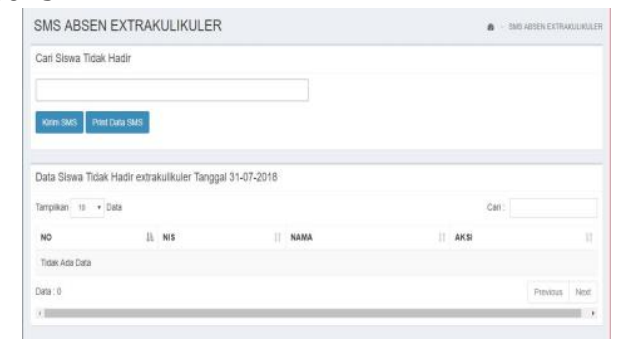

Gambar 4.13 SMS absen (ekstrakurikuler)

\section{Inbox}

Menu inbox ini berisiskan pesan balasan dari wali murid setelah admin mengirimkan informasi kesiswaan.

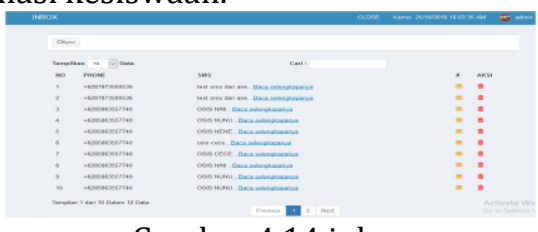

Gambar 4.14 inbox

\section{KESIMPULAN DAN SARAN}

\section{A. Kesimpulan}

Berdasarkan pada hal-hal yang peneliti telah bahas pada bab-bab sebelumnya, maka peneliti menarik kesimpulan, bahwa :

Dengan adanya sistem informasi kesiswaan menggunakan metode ekstreme programming (XP) ini dapat mempermudah pihak SMA Negeri 1 Praya Tengah dalam proses pengolahan data siswa serta dalam proses penyampaian informasi kepada wali murid, baik dari segi informasi kesiswaan, informasi jadwal semester, dan jadwal kegiatan ekstrakurikuler.

\section{B. Saran}

Dari hasil kesimpulan maka peneliti dapat memberikan saran untuk penelitian selanjutnya bahwa perlu adanya penyempurnaan Dalam pengembangan sistem masih ditemukan berbagai macam kekurangan sehingga diperlukan pengembangan sistem lebih lanjut.

\section{DAFTAR PUSTAKA}

[1] Afrina, Mira, and Ali Ibrahim. "Pengembangan Sistem Informasi SMS Gateway Dalam Meningkatkan Layanan Komunikasi Sekitar Akademika Fakultas Ilmu Komputer Unsri." Jurnal Sistem Informasi 7.2 (2015).

[2] Gani, Abdul, and Wire Baye. "Sistem Informasi Praktek Kerja Industri Pada SMK Islam Sirajul Huda Paok Dandak." Jurnal Manajemen Informatika dan Sistem Informasi 1.1 (2018): 52-56.

[3] Hasenda, Dianvia. Sistem informasi manajemen berbasis Short Message Services (SMS) Gateway di SMP al Islam Krian Sidoarjo. Diss. UIN Sunan Amel Surabaya, 2017.

[4] Kusprianto, Achmad, and Kusnawi Kusnawi. "Perancangan Sistem Informasi Kesiswaan Berbasis SMS Gateway di SMP Negeri 9 Berau Kalimantan Timur." Data Manajemen dan Teknologi Informasi 13.3 (2012).

[5] Nurlaela, Fetty. "Aplikasi SMS Gateway Sebagai Sarana Penunjang Informasi Perpustakaan Pada Sekolah Menengah Pertama Negeri 1 Arjosari." IJNS-Indonesian Journal on Networking and Security 2.4 (2013).

[6] Nidhra, Srinivas, and Jagruthi Dondeti. "Black box and white box testing techniques-a literature review." International Journal of Embedded Systems and Applications (IJESA) 2.2 (2012): 29-50.

[7] Oktavianti, Intan. "Pengertian ERD (Entity Relationship Diagram)." URL: http://intanstemapal24. blogspot. com/2014/08/pengertian-erd-entity relationship. html pada tanggal 3 (2014).

[8] Putri, Lely Deviana, and Azis Ahmadi. "Perancangan Sistem Informasi Penerimaan Siswa Baru Pada Sekolah Menengah Kejuruan Negeri 3 Pacitan." IJNS-Indonesian 
Journal on Networking and Security 3.4 (2014).

[9] Sunardi, Hari Murti, and Hersatoto Listiyono. "Aplikasi SMS

Gateway." Dinamik 14.1 (2009).

[10] Imtihan, K., Hadawiyah, R., \& Lombok, H. A. S. (2018). Sistem Informasi Penggajian Guru Honorer Menggunakan Konsep Agile Software Development dengan Metodologi Extreme Programming (XP) pada SMK Bangun Bangsa. IJNS-Indonesian Journal on Networking and Security, 7(2).

[11] Haris, N., Imtihan, K., \& Ashari, M. (2018). PERANCANGAN SISTEM INFORMASI PENGOLAHAN DATA NILAI SISWA BERBASIS WEB DI SMKN 1 PRAYA. Jurnal Manajemen Informatika dan Sistem Informasi, 1(2), 55-61.
[12] Suryantara, I. Gusti Ngurah, S. Kom, and M. Kom. Merancang Applikasi dengan Metodologi Extreme Programming. Elex Media Komputindo, 2017.

[13] Pitriyawati, M., \& Imtihan, K. (2018). Sistem Informasi Kenaikan Pangkat Karyawan Pada Dinas Pekerjaan Umum (PU) Dan Energi Sumber Daya Mineral (ESDM) Kabupaten Lombok Tengah. Jurnal Manajemen Informatika dan Sistem Informasi, 1(1), 31-38.

[14] Lombok, K. I. S. (2015). Perencanaan Strategi Sistem Informasi Pendidikan Pada Sekolah Tinggi Manajemen Informatika dan Komputer (STMIK) Lombok. Bianglala Informatika, 3(2). 